\title{
Development of Gulley Ali Beg Gorge in Rawandooz Area, Northern Iraq
}

\author{
Varoujan K. Sissakian1, Mawaheb F. Abdul Jab'bar², Nadhir Al-Ansari³, Sven Knutsson ${ }^{3}$ \\ ${ }^{1}$ Erbil, Iraq \\ ${ }^{2}$ Iraq Geological Survey, Baghdad, Iraq \\ ${ }^{3}$ Lulea University of Technology, Lulea, Sweden \\ Email: varoujan49@yahoo.com, mawaheb geosurv@yahoo.com, nadhir.alansari@Itu.se, \\ Sven.Knutsson@ltu.se
}

Received 27 December 2014; accepted 12 January 2015; published 19 January 2015

Copyright (C) 2015 by authors and Scientific Research Publishing Inc.

This work is licensed under the Creative Commons Attribution International License (CC BY).

http://creativecommons.org/licenses/by/4.0/

(c) (i) Open Access

\section{Abstract}

The northern and northeastern parts of the Iraqi exhibit different types of gorges. Some of them are few kilometers in length and few hundred meters in height. The most significant gorge is the Gulley Ali Beg gorge in Rawandooz area; its length is about $12.1 \mathrm{Km}$, with maximum and minimum widths of 100 to $155 \mathrm{~m}$, respectively. The water in the gorge flows in two opposite directions, from the north and south through two streams; they meet in the middle of the gorge, and then change the streams direction towards west; for few kilometers before it merges in the Greater Zab River. The gorge runs within very hard thickly bedded to massive carbonate rocks, which belong to Sarmord, Qamchuqa and Bekhme formations (Cretaceous in age). To the right of the southern entrance; stands Korak anticline, whereas to the left occurs Peris anticline. To the right of the northern entrance; stands Handreen anticline, whereas to the left is Bradost anticline; represented by Balikian Mountain. The gorge is developed by continuous lateral and vertical growth of the four mentioned anticlines, with continuous incision of both streams, Rawandooz from the north and Khlaifan from the south. Both shifted their courses, continuously as indicated from the presence of many wind gaps in the aforementioned anticlines.

\section{Keywords}

Gorge, Lateral Propagation, Watergap, Windgap, Morphometry, Iraq

\section{Introduction}

The study area is located in Erbil Governorate, North Iraq, between Rawandooz town, in the north and Khlaifan 
town in the south (Figure 1). It can be reached by paved roads from different directions, from Erbil in the south, from Ranya in the east, from Aqra in the west, and from Zibar in the north. Gulley Ali Beg gorge is one of the most well-known gorges in Iraq. It is located near Rawandooz town and being a famous summer resort. The gorge is $12.1 \mathrm{Km}$ in length, whereas its width ranges from 100 to $155 \mathrm{~m}$. It is formed from two large streams. The northern one is larger and called Rawandooz River, in which Zil Gulley stream merges before the northern entrance of the gorge, whereas the southern one is called Khlaifan stream, which merges in the middle of the gorge into the Rawandooz River, which then runs westwards to merge with the Greater Zab River, $18 \mathrm{Km}$ farther on.

Specialized studies, dealing with types of gorges in Iraq, are very rare. The following works, however, deal with the types of gorges, their genetic origin and reasons of their developments.

- Al-Maamar et al. (2009) [1] conducted geomorphological study of the Greater Zab River and mentioned the gorge and its characteristics, without explaining its origin.

- Sissakian and Abdul Jab’bar (2010) [2] studied assorted gorges in the northern and northeastern parts of Iraq. They gave different explanations for their developments, related mainly to tectonic and neotectonic movements, and some geomorphological features.

- Sissakian (2010) [3] carried out a neotectonic study on the Darbandi Bazian gorge and revealed that the water gap had changed to a wind gap due to a neotectonic activity in the area.

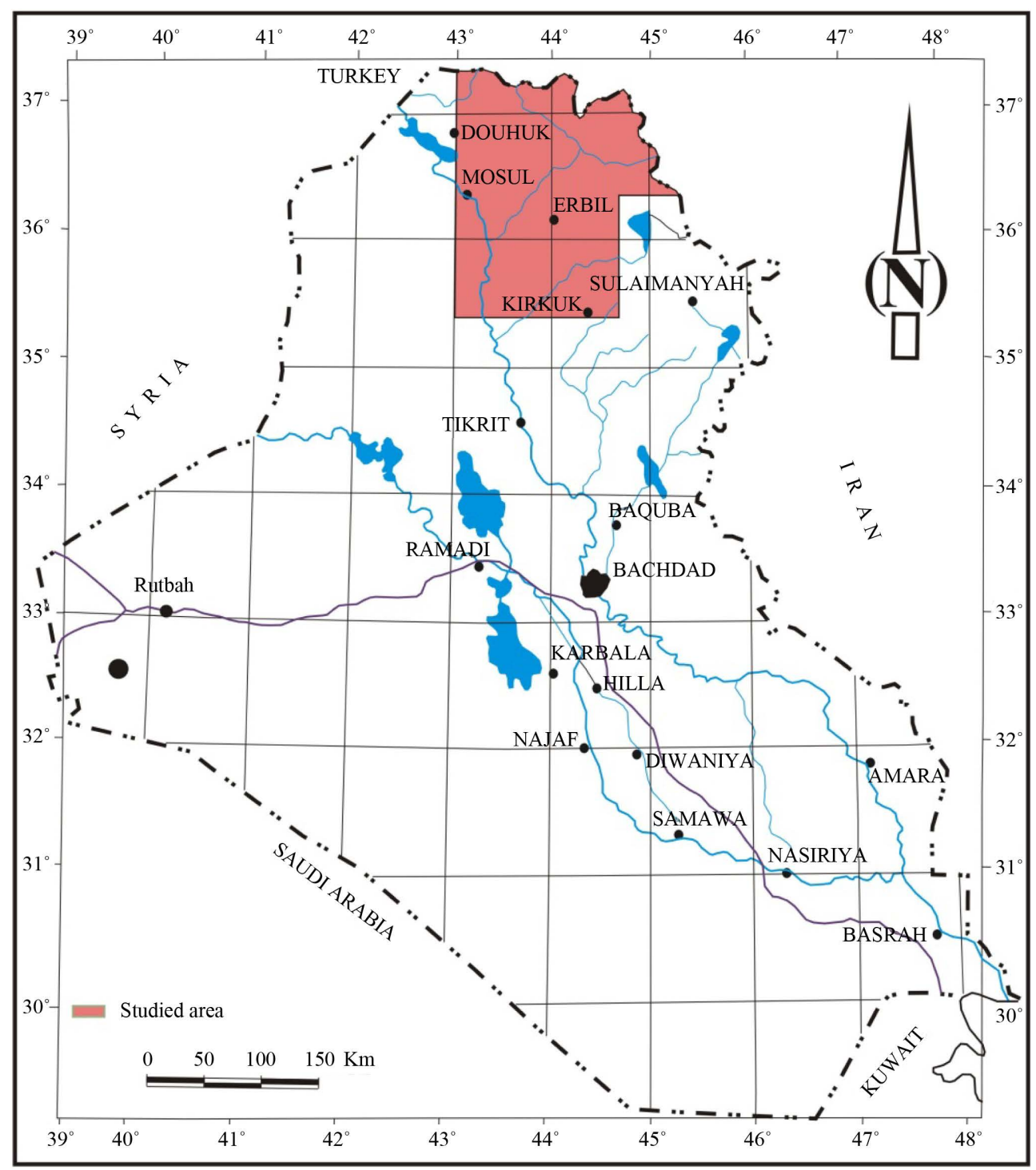

Figure 1. Location map of the studied area. 
- Al-Mamaar et al. (2011) [4] compiled the Geomorphological maps of Erbil and Mahabad Quadrangles, at scale 1: 250,000, where the gorge is located. They considered the erosional cliffs surrounding the gorge.

- Abdul Jab’bar (2012) [5] studied the development of the wind gaps and water gaps in many anticlines, though out of the studied area. She attributed the development of the water gaps and wind gaps to the lateral propagation and growth of the folds.

- Sissakian and Abdul Jab’bar (2013) [6] studied the morphometry of the three tributaries of the Adhaim River and gave explanation for the developments of the water gaps and wind gaps in the involved area.

- Sissakian (2013) [7] conducted a morphotectonic study of the Greater Zab River. He considered the Galley Ali Beg gorge as a unique and complex one.

- Sissakian and Fouad (2013) [8] updated the Geological Map of Rawandooz Quadrangle at scale of 1:100,000, which originally was compiled from the interpretation of aerial photographs. The exposed formations and anticlinal axis were presented in the map.

- Sissakian and Fouad (2013) [9] updated the Geological Map of Erbil and Mahabad Quadrangles, at scale of 1:250,000, in which the exposed formations and the details of the structural elements are presented.

- Al-Kubaisy and Abdul Jab’bar (2014) [10] conducted a morphotectonic study on many anticlines within the High Folded Zone and attributed the developments of the gorges, water gaps and wind gaps to the lateral propagation of the folds.

- Sissakian et al. (2014) [11] reviewed the geomorphology of the High Folded Zone area. They concentrated on the lateral propagation and growth of the folds and their influence on the development of the water gaps and wind gaps. They also considered the Galley Ali Beg gorge as a unique and a complex gorge in its development.

The aim of this study is to delineate the morphometry of the Gulley Ali Beg gorge and to reveal its complex development, being a very rare gorge in which the water flows in two opposite sides.

\section{Materials and Methods}

To achieve the aim of this study, the following materials were used:

- Geological maps, at scale of 1:100,000 and 1:250,000;

- Topographical map, at scale of 1:100,000;

- Geological reports concerning the study area;

- Google Earth and Satellite images;

- Google Earth and Satellite images;

- Digital Elevation Model (DEM);

- Relevant published articles.

The geological and topographical maps with the Google Earth and Satellite images were used to recognize the morphometric details of the gorge. GIS techniques were used to measure the height, gradient and indications of the lateral growth of the existing anticlines, and to indicate the water gaps, wind gaps and the type of the drainage system in the surroundings. Geological maps of Rawandooz at scale 1:100,000 [8] and Erbil and Mahabad Quadrangles at scale 1:250,000 [9] were reviewed to observe the relation between the exposed geological formations, anticlines and the involved gorge.

\section{Geological Setting}

The geological setting of the studied area is reviewed based on the available data [8] [9].

\subsection{Geomorphology}

Within the studied area only Structural-Denudational units are developed, among which are two units. Dissected slopes well developed in the studied area. The dip slopes of the hard rocks are dissected by valleys, which usually run parallel or semi parallel to the dip direction.

Anticlinal Ridges are also well developed in the studied area, surrounding Galley Ali Beg gorge and within the anticlines and deeply cut valleys. The length of the ridges may reach up to few kilometers.

Geodynamical Processes are well noticed through landslides, toppling and rock fall. Land Slides are rarely developed, usually along the ridges of the anticlines and/or structural ridges. Toppling is a very common phe- 
nomenon along the ridges, which are developed along the gorge and banks of the deeply cut valleys. The size of the toppled blocks ranges from $(<0.5-5) \mathrm{m}^{3}$. Rock fall phenomenon is very rare; it may be present along the steep slopes and high cliffs.

Different types of weathering and erosion are acting in the studied area.

Mechanical weathering is more active in the studied area, as indicated by the presence of large areas of very rough topography. However, chemical weathering is partly active; especially in some karstified limestones of different formations, forming caves, like the well-known Shnider cave in Bradost Mountain, and other karst forms, such as Karnes in Balikian and Korak anticlines.

The main erosional agent in the studied area is the water. Two types of erosion are developed: Gulley and Rill. Gulley erosion is developed along Galley Ali Beg gorge (Figure 2) and other main valleys. Rill erosion is developed on slopes along anticlinal ridges.

\subsection{Stratigraphy}

The exposed formations are reviewed briefly hereinafter, depending on the work of [8] [9] [12].

- Sarmord Formation (Lower Cretaceous): Consists of alternations of blue marls with marly limestone, and of limestones and marl. The thickness is about $400 \mathrm{~m}$.

- Qamchuqa Formation (Lower Cretaceous): Consists of massive limestones and dolomites, dark grey in colour. The thickness ranges from (300 - 500) $\mathrm{m}$.

- Aqra-Bekhme Formation (Upper Cretaceous): Consists of well bedded limestones and dolostones, locally bituminous, coralline and recrystallized, very hard, light grey in colour. The thickness ranges from (100 - 315) $\mathrm{m}$.

- Shiranish Formation (Upper Cretaceous): Consists of thinly well bedded marly and chalky limestones, followed (upwards) by thin bedded or papery marl, with some marly limestone beds too. It is exposed out of the gorge. The thickness ranges from (200 - 500) $\mathrm{m}$.

- Tanjero Formation (Upper Cretaceous): Consists of alternation of dark green shale, claystone, sandstone and siltstone some conglomerates occur in the upper part and some marlylimestones in the lower part. It is exposed outside the gorge. The thickness ranges from $(400$ - 1000) $\mathrm{m}$.

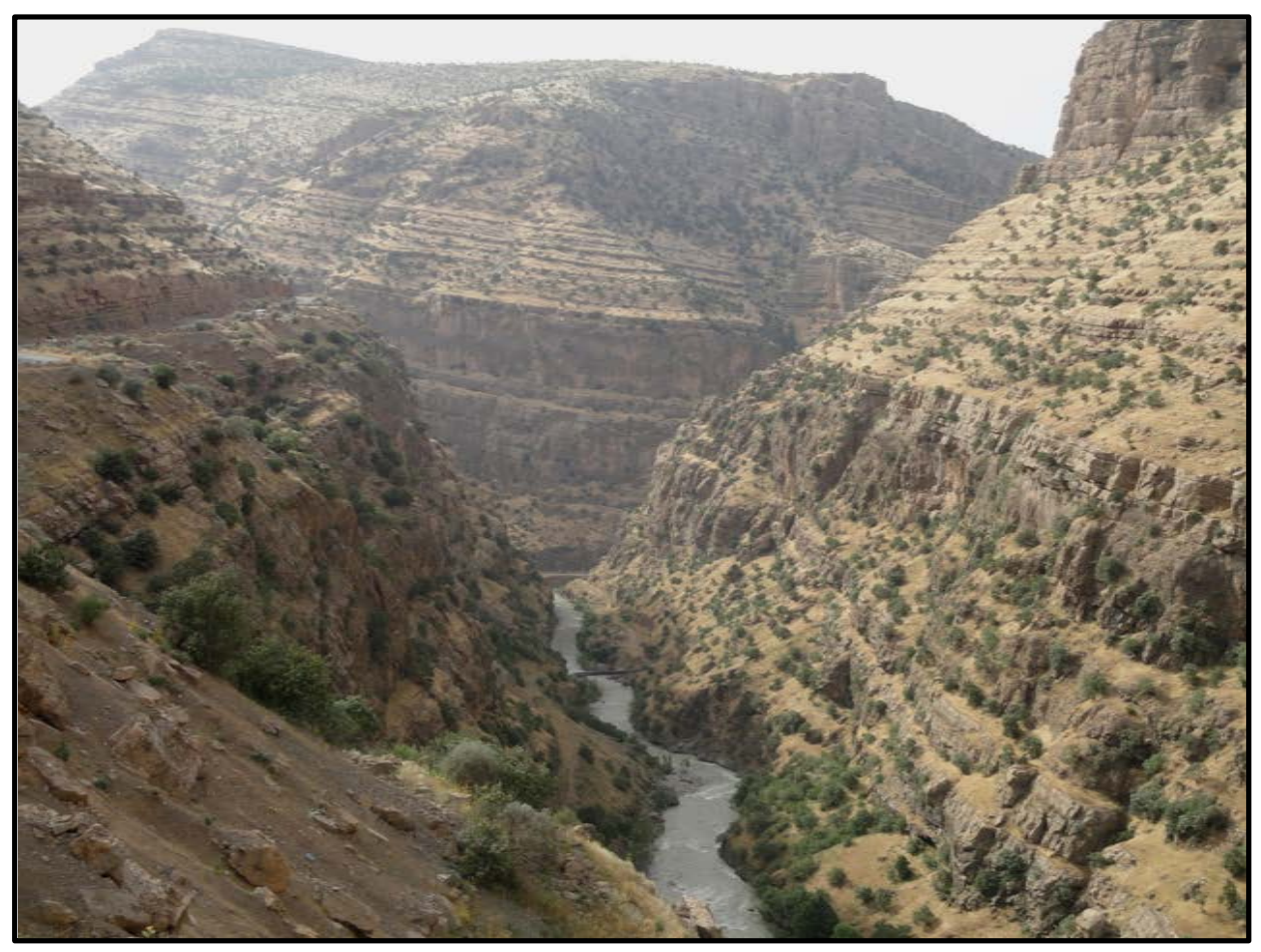

Figure 2. Galley Ali Beg, a tributary of the Rawandooz River, exhibiting deep gulley erosion (forming the largest water gap in Iraq). 


\subsection{Structural Geology}

The studied area is located within the High Folded Zone, which belongs to the Unstable Shelf of the Arabian Plate [13]. However, Fouad [14] considered the Unstable Shelf as the Outer Platform of the Arabian Plate.

Many anticlines and synclines are developed with a NW-SE trend. They are from the north to the south: Balikian, Zozik, Handreen, Peris and Korak. Some of the anticlines exhibit erosional ridges and steep valleys. Many anticlines have influenced the course of the streams, usually forming curves along their plunge areas. However, locally, the courses of the rivers cross the anticlines perpendicularly, due to many reasons [2].

\subsection{Neotectonics}

The Alpine Orogeny is still active; therefore, the studied area is up warped. The amount of up warping ranges between $(0-1000) \mathrm{m}$, the rate of the up warping is $0.8 \mathrm{~cm} / 100 y e a r s$. These data are acquired from the Neotectonic Map of Iraq [15].

\section{Gulley Ali Beg Gorge}

After the text edit has been completed, the paper is ready for the template. Duplicate the template file by using the Save As command, and use the naming convention prescribed by your journal for the name of your paper. In this newly created file, highlight all of the contents and import your prepared text file. You are now ready to style your paper.

\subsection{Characteristics}

Gulley Ali Beg gorge is about $12.1 \mathrm{Km}$ in length, whereas its width is about $100 \mathrm{~m}$ in the southern entrance, and $155 \mathrm{~m}$ in the northern entrance. The highest point in the southern entrance is the peak of Korak Mountain, with height of $2128 \mathrm{~m}$ (a.s.l.), whereas in the northern entrance is the peak of Handreen Mountain, with height of $2598 \mathrm{~m}$ (a.s.l.). The height of the southern entrance is $737 \mathrm{~m}$ (a.s.l.), whereas the height of the northern entrance is $705 \mathrm{~m}$ (a.s.l.). The height of the merging point of the Khlaifan stream into the Rawandooz River is $678 \mathrm{~m}$ (a.s.l.).

\subsection{Drainage System}

Gulley Ali Beg gorge consists of two streams that flow opposite to each other, being the unique gorge in Iraq and may be very rare in the world. The Khlaifan stream flows from the south towards northeast for about 4.25 $\mathrm{Km}$, as measured from the entrance, then merges into the Rawandooz River, which flows from the northern entrance towards WSW then west, and then towards southwest, for $7.85 \mathrm{Km}$, it flows northwestwards; after merging with Khlaifan stream (Figure 3). Then the Rawandooz River merges with the Greater Zab River, $19 \mathrm{Km}$ away from the point where Khlaifan stream merges in and the former flows out of the gorge (Figure 3).

The Khlaifan stream, before its entrance into the gorge, runs towards northwest in the trough of a syncline in between Hareer anticline; in the south and Korak anticline; in the north. It changes its direction towards northeast due to the presence of the southeastern plunge of Peris anticline, and crosses the area between plunges of Korak and Peris anticlines and enters the gorge.

It is worth to mention that Khlaifan stream is the only one in the north and northeastern parts of Iraq that flows northeastwards. This abnormal flow direction is discussed hereinafter in the "Discussion" paragraph, of this study.

The Rawandooz River is a long river, its eastern reaches lie almost in the international boundaries between Iraq and Iran, near Haj Omran, and it also drains Hasarost and Garda Mand mountains, which is a very large area. Before the rivers entrance to the gorge, Zil Gulley stream merges with, which flows towards southeast in the trough of a syncline in between Bradost and Zozik anticlines. Therefore, the Rawandooz River crosses the area between the plunges of Zozik and Bradost anticlines and enters the gorge from its northern entrance.

\subsection{The Southern and Northern Entrances}

The southern entrance is controlled by the steeply dipping beds of the northwestern plunge of Korak anticline (2128 m) (Figure 3), which faces the eastern plunge of Peris anticline (1251 m), with a small hill, whose height 


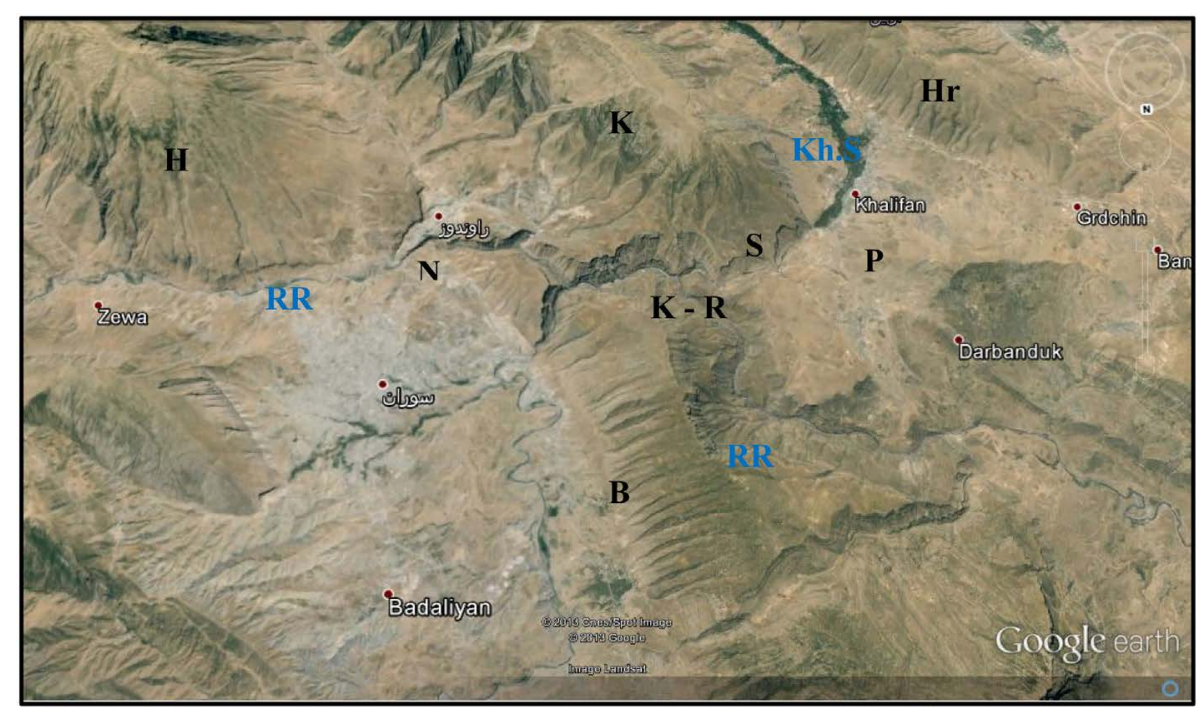

Figure 3. Google earth image of the studied area (facing south). Note the steep northwestern plunges of Handreen $(\mathrm{H})$ and Korak (K) anticlines; controlling the Northern (N) and Southern (S) entrances of the gorge, respectively. Also note the merging of Khlaifan Stream (Kh.S) into the Rawandooz River (RR) at the point (K-R); almost in the middle of the gorge, and its flow out of the gorge. Anticlines: $\mathrm{B}=$ Bradost; $\mathrm{P}=$ Peris; and $\mathrm{Hr}=$ Hareer.

is $839 \mathrm{~m}$. Therefore, the height difference between the right and left sides of the southern entrance is about 1291 $\mathrm{m}$. The northern entrance is controlled by the steeply dipping beds of the northwestern plunge of Handreen anticline (Figure 3 and Figure 4), which faces the southeastern plunge of Bradost anticline, represented by Garwa Bern peak with a height of 1577 m (a.s.l.); within Balikian Mountain of Bradost Range.

\subsection{Gradients}

The gradient of the Khlaifan stream within the gorge is about 1.4:100, whereas that of the Rawandooz River is 0.35:100. It is clear that the gradient of both streams is very low, which is not the same case with the gradients of the gorges escarpment influenced by fluvial erosion. The gradient of the right and left sides' embankment in the southern entrance are 33.76:100 and 12.82:100, respectively, whereas those of the northern entrance are 16.46:100 and 13.82:100, respectively (Figures 3-5).

\section{Lateral Propagation}

If a fold starts to propagate laterally and the incision rate of the river is higher than the uplift rate of the fold; a gorge, called "water gap", establishes. If the incision rate of the river becomes lower than the uplift rate of the folds during further growth of the anticline, the river gets defeated and diverted leaving behind a dry valley called "wind gap" [16] [17]. Moreover, different geomorphological processes may contribute, accelerate or even forms water gaps and may change them to wind gaps [2].

\section{Indications for Lateral Propagation}

Many anticlines in the studied area show clear indications for lateral propagation. Among them is Handreen anticline, which shows many indications for lateral propagation towards northwest, these are: 1) Semi radial drainage in the plunge area; 2) Asymmetric forked tributary network; and 3) Three successive wind gaps [18], and 4) The shifted Rawandooz River (Figure 6), which is a typical example as described by [18] (Figure 7).

When thoroughly inspecting the course of the Rawandooz River, it can be clearly seen that the river was flowing almost perpendicular to Handreen anticline and it was continuously shifting northwestwards, as indicated in the aforementioned four points (Figure 6). Moreover, Figure 8 clearly shows the direction of the Rawandooz River before it is diverted into its present course. The river was crossing vertically not only Handreen anticline, but also Zozik and Tanun anticlines, respectively. 


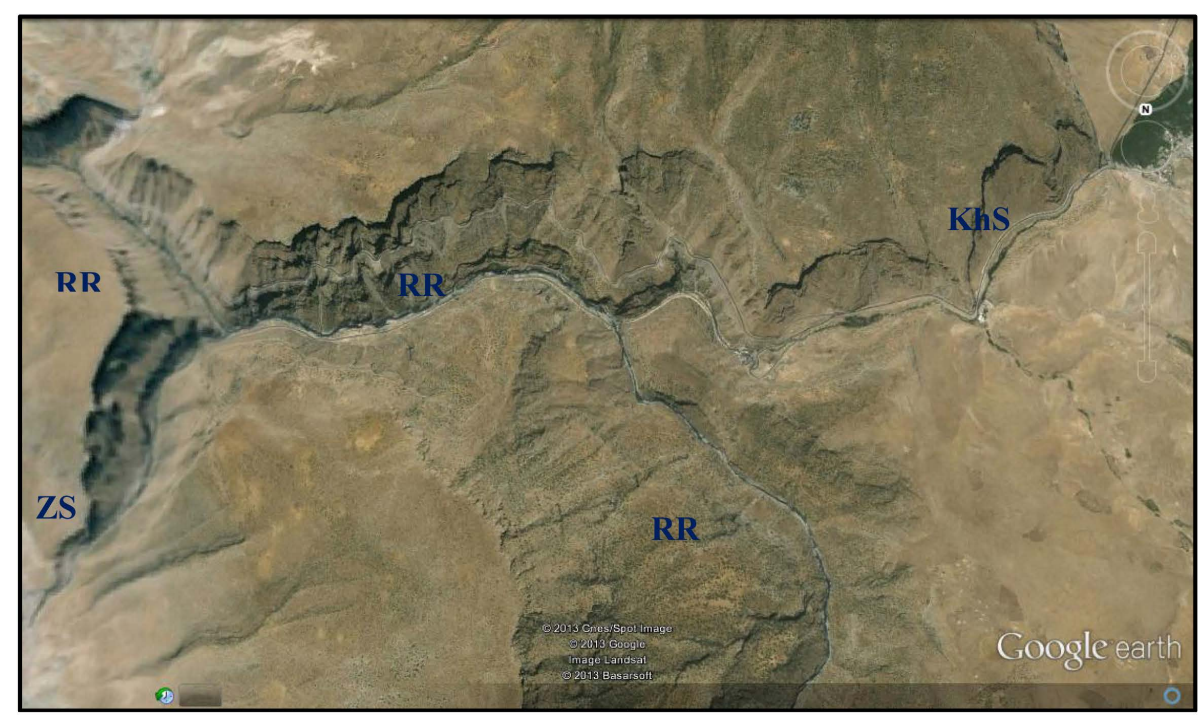

Figure 4. Google earth image (facing south). Note the merging of the Khlaifan stream (KhS) into the Rawandooz River (RR), before leaving the gorge. Also note the merging of Zil Gulley stream (ZS) with the Rawandooz River in the northern entrance of the gorge.

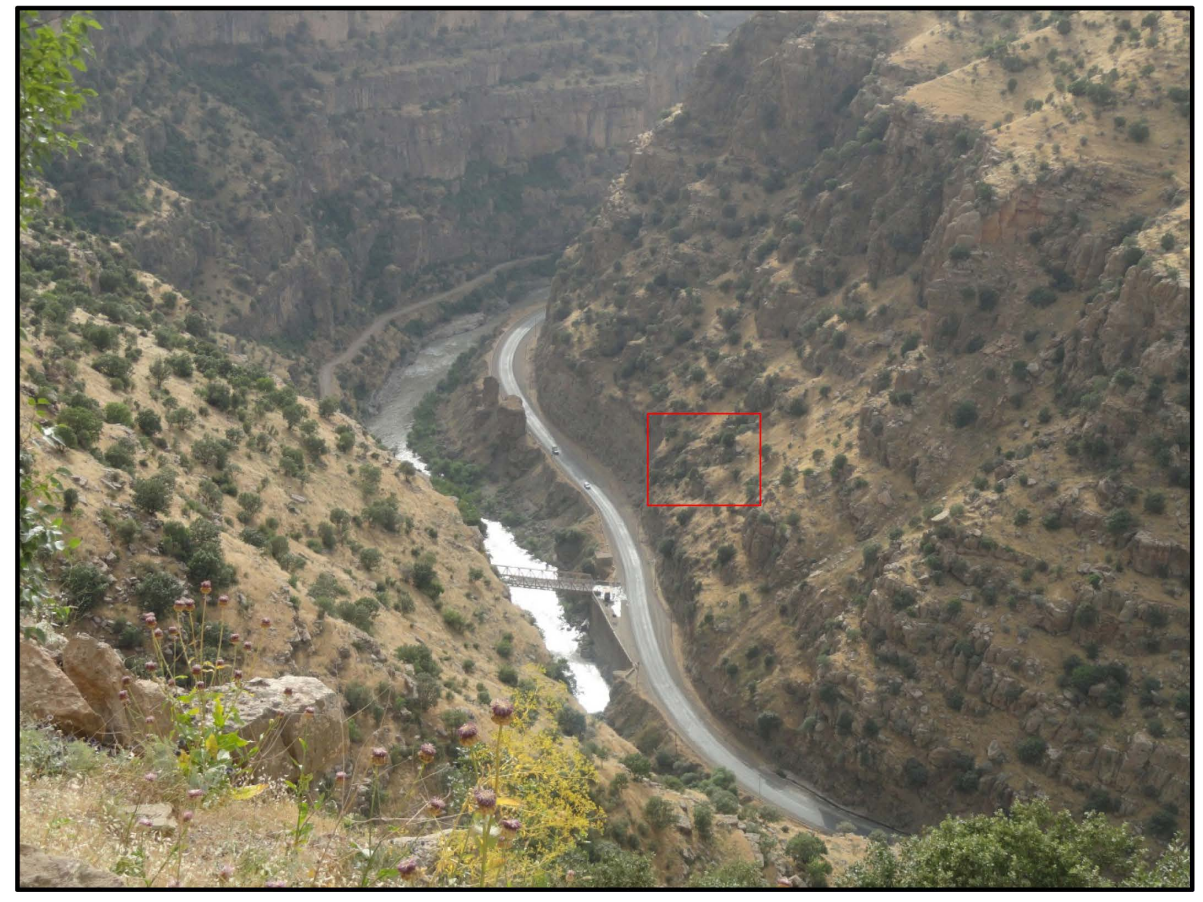

Figure 5. Rawandooz River crossing Gulley Ali Beg gorge. Note the steep gradient of the escarpment, compare the height with the width of the road and the size of the two cars, near the bridge.

\section{Results}

Gulley Ali Beg gorge is one of the longest and narrowest gorges in the whole Iraqi territory. The depth of the gorge ranges from (300 - 350) $\mathrm{m}$, and from (100 - 155) $\mathrm{m}$ in width, carved in very hard thickly bedded and massive carbonate rocks, which belong to Sarmord, Qamchuqa and Bekhme formations.

The water flows in the Gulley Ali Beg gorge in two opposite directions (Figure 9). From the southern entrance, the Khlaifan stream flows northeastwards, whereas from the northern entrance, the Rawandooz River 


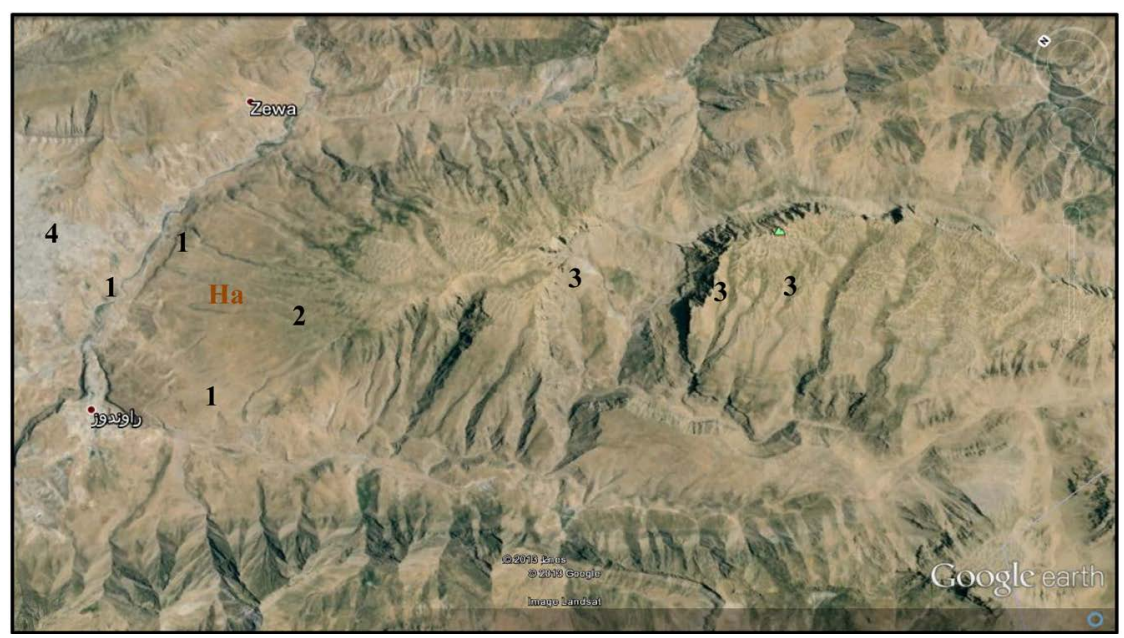

Figure 6. Google earth image (facing northeast) of Handreen anticline (Ha). Note the aforementioned four indications: 1 = Radial drainage; 2 = Forked drainage; 3 = Wind gaps; and 4 = Shifted Rawandooz River.

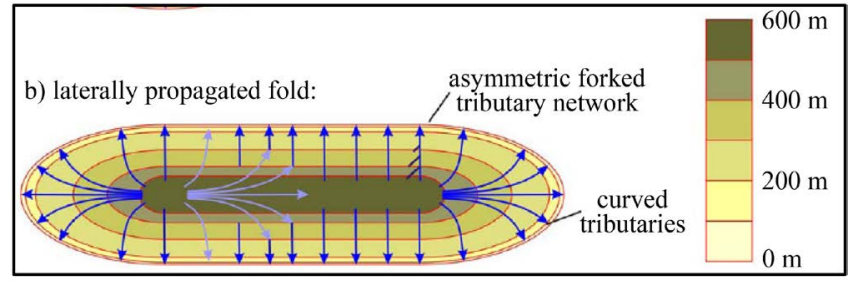

$\longrightarrow$ stream course

$\longrightarrow$ inherited

Figure 7. Map view with contour lines of an idealized embryonic cylindrical fold with its theoretical tributary pattern that has grown in length for an idealized fold (after [18]).

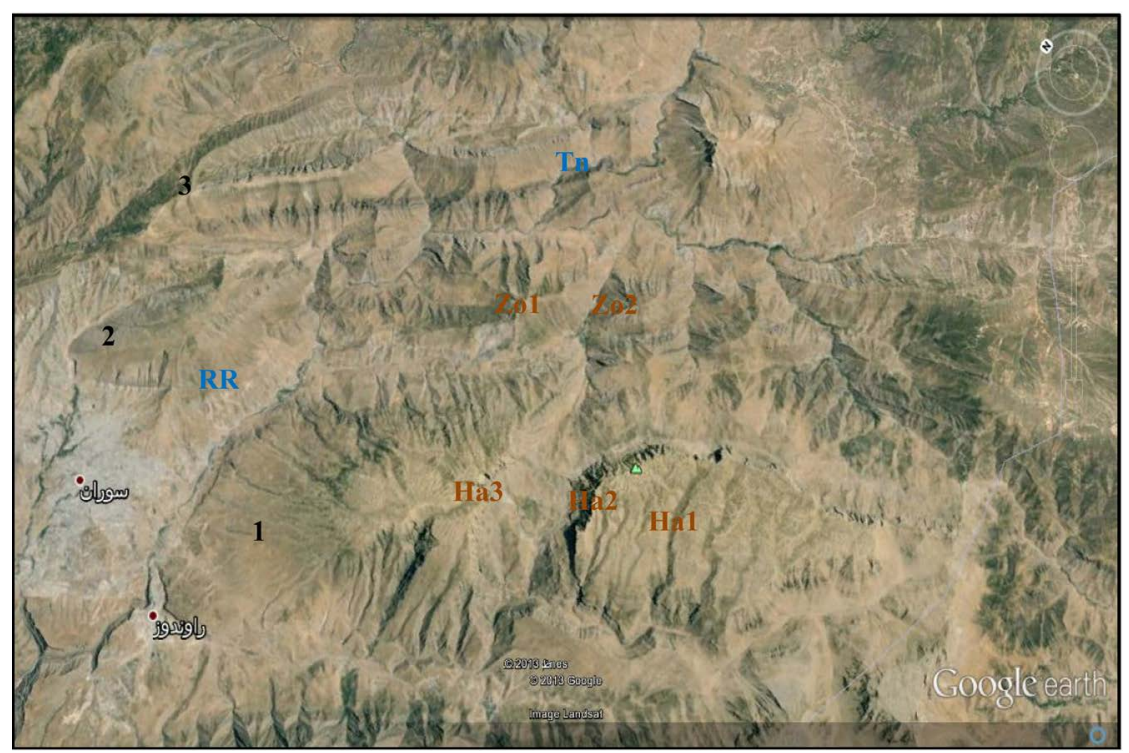

Figure 8. Google earth image (facing northeast) of Handreen (1), Zozik (2) and Tanun (3) anticlines. Note the nowadays course of the Rawandooz River (RR) crossing Tanun Anticline (Tn), then the older courses, which were flowing NE-SW, crossing Zozik anticline (Zo) and then Handreen anticline (Ha3) through successive wind gaps (Zo1, $\mathrm{Zo} 2$ and, Ha1, Ha2 and Ha3) 


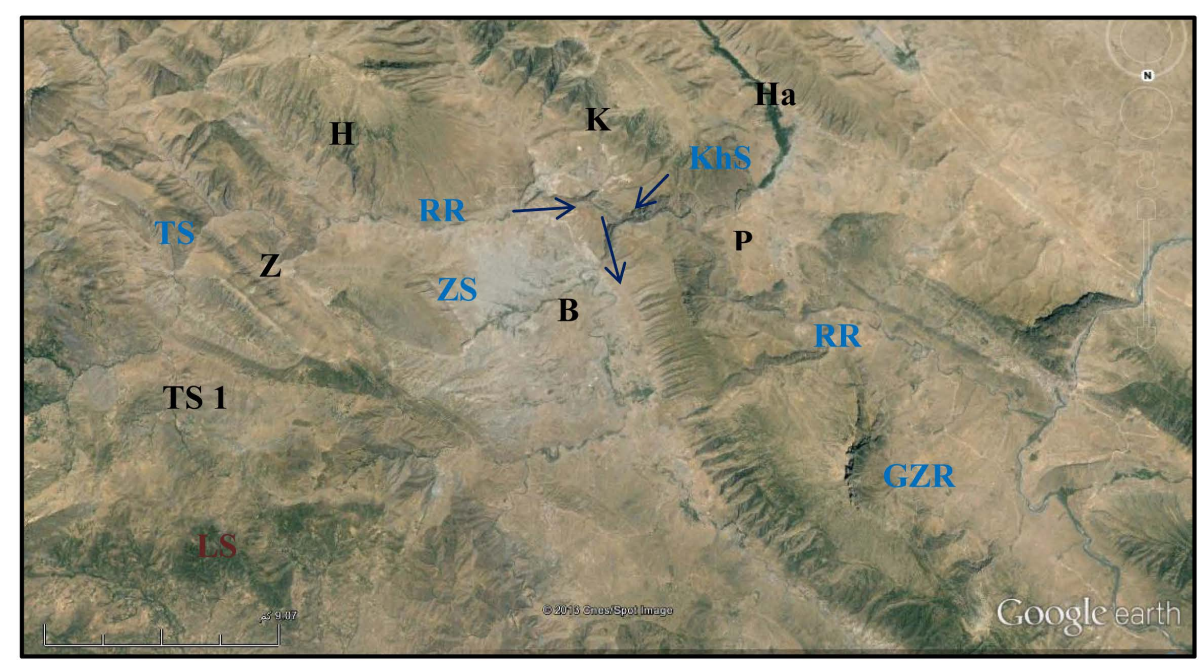

Figure 9. Google earth image of the studied area and near surroundings; facing south. Anticlines: Z = Zozik; H = Handreen;B = Bradost; Ha = Hareer; $\mathrm{P}=$ Peris. Rivers: GZR = Greater Zab; RR = Rawandooz. Streams: KhS = Khlaifan; TS = Tanun; ZS = Zil Gulley; LS = Land slide area; TS 1 = Old course of Tanun stream.

flows towards WSW, they merge together almost in the middle of the gorge, and then the Rawndooz River flows out of the gorge; westwards to merge in the Greater Zab River.

\section{Discussion}

Morphotectonics refers to forms and shapes that have evolved in the past or in recent times as a result of past or recent tectonic activity. The most vivid evidences of past tectonic activity can be assessed through drainage lines, in any area which are guided and controlled by physical structures over which they flow [19]. Following this concept and that mentioned by, the scenario of evolution of the Galley Ali Beg gorge is discussed and revealed. The main evidences used are the presence of water gaps and wind gaps, besides other evidence mentioned by [2] [18].

\subsection{The Gulley Ali Beg Gorge}

The gorge is carved in very hard thickly bedded and massive carbonates, with length of $12.1 \mathrm{Km}$, width range of (100 - 155) $\mathrm{m}$ and depth of the escarpments range of $(150$ - 700) $\mathrm{m}$, whereas the total depth reaches about 1300 $\mathrm{m}$. The water flows in the gorge in two opposite directions from the north and the south, by Rawandooz River and Khlaifan stream, respectively, forming a very rare and abnormal case.

\subsection{Rawandooz River}

The Zozik and Handreen anticlines, before their lateral growth, were plunging in the areas marked as ZRR 1 and RR 1, then in ZRR 2 and RR 2, respectively (Figure 10), where the Rawandooz River was originally flowing; following the plunge of the anticlines, whereas its present location (RR) also follows the plunge of the Korak anticline, but the last plunge area. Moreover, the old plunge of Zozik anticline was at the area marked as ZRR 1 and ZZR 2 (Figure 10), where Tanun Stream crosses now the anticline from a water gap, which was abandoned to form a wind gap, due the lateral growth of the Zozik anticline. The stream was following the plunge in the area marked as TS 1 (Figure 9). However, the course of the stream is blocked by a huge landslide (Area LS in Figure 9) and the stream has returned to its abandoned wind gap location to flow again in its older course, through a water gap (TS in Figure 10).

When inspecting thoroughly the old course of the Tanun stream, crossing Tanun anticline, which is the same present course (TS); as described, it is clearly seen that it runs along a straight line with the older course of Rawandooz River (ZRR2 and HRR2) (Figure 10). This indicates that both Handreen and Zozik anticlines were laterally growing with the same rate, which is a normal case, since both lie within the same tectonic zone, the 


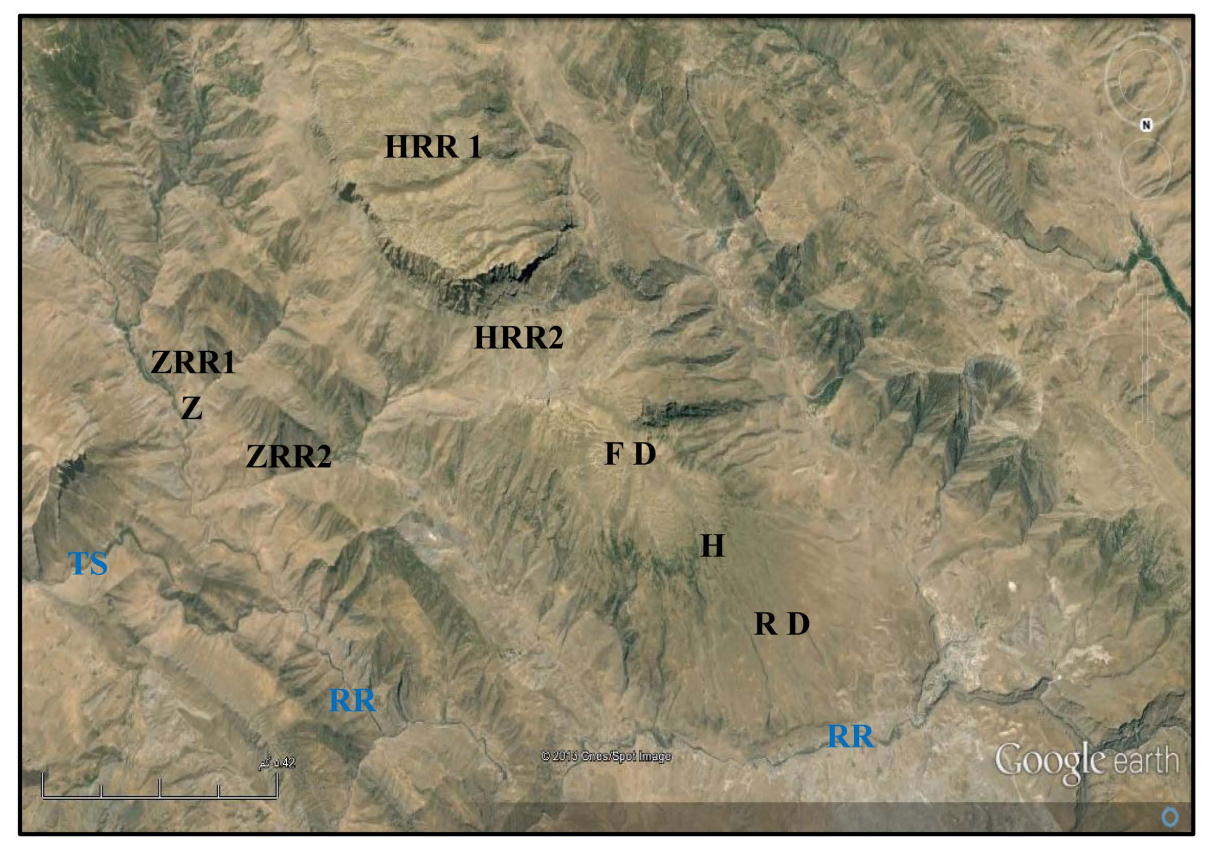

Figure 10. Google earth image of the Rawandooz River (RR); crossing Zozik (Z) and Handreen (H) anticlines. TS = Tanun stream. Note the old courses of the Rawandooz River (ZRR 1, PR 1, ZRR 2 and RR 2) before the growth of the anticlines; forming a wind gap, FD = Forked drainage; $\mathrm{RD}=$ Radial drainage (image facing south).

Imbricate Zone (Fouad, 2012). Indication for the lateral growth is very clear on the plunge of Handreen anticline, the fork shaped drainage (FD) and radial drainage (RD), (Figure 9) and the presence of wind gaps, which are the same indications mentioned by Ramssey et al. (2008) for the lateral growth.

\subsection{Khlaifan Stream}

Khlaifan stream flows in the trough of the syncline between Korak and Handreen anticlines (Figure 11). The old course (OC) was almost parallel to the existing road and was crossing Hareer anticline around its northwestern plunge area (WiG). As Hareer anticline was laterally growing; the stream was pushed northwest ward, and because the incision of the stream was lower than the rate of the growth, the stream abandoned its course leaving a wind gap (WiG), and a new course was developed at WG. This course also was abandoned leaving another wind gap; the new crossing was at NC (Figure 11).

The evidence for the aforementioned courses of Khlaifan stream is more clearly seen in Figure 12. The first crossing was in the location of WiG (Figure 11 and Figure 12), which represents the old plunge area of Hareer anticline; before its growth. After crossing Hareer anticline and the Pila Spi ridge at the point 1 (Figure 12), a large alluvial fan (AF) is formed; as usual. The second crossing was at WG (Figure 11 and Figure 12), and another alluvial fan is formed at the crossing point of the Pila Spi ridge (point 2, Figure 12). The last normal crossing of the stream to Hareer anticline was at NC (Figure 11 and Figure 12), which represents the present plunge area of the anticline. Because the stream was following the plunge, which is the normal case, and flowing out of the anticline at the point 3 (Figure 12), therefore, no alluvial fan is developed. This is attributed to the fact that the stream had no sudden gradient change, and it was not flowing out of a gorge (Figure 12). However, this crossing was also abandoned due to shifting of the Khlaifan stream towards north, and changing its course towards the northeast. Therefore, two wind gaps are present within Hareer anticline (WiG and WiG2, Figure 12). Moreover, the last crossing, although was abandoned by Khlaifan stream, and returned to the second wind gap to cross the anticline by a small stream. The deflection point of this stream from the original one is clearly seen at the point DP (Figure 11).

The Khlaifan stream had shifted its course from the crossing Hareer anticline to another course, which is in opposite direction, towards NNE; through Galley Ali Beg gorge (Figure 9 and Figure 11). This abnormal shift of the course is attributed to: 1) A normal fault along the plunge area of Korak Anticline (FE, Figure 9), with 


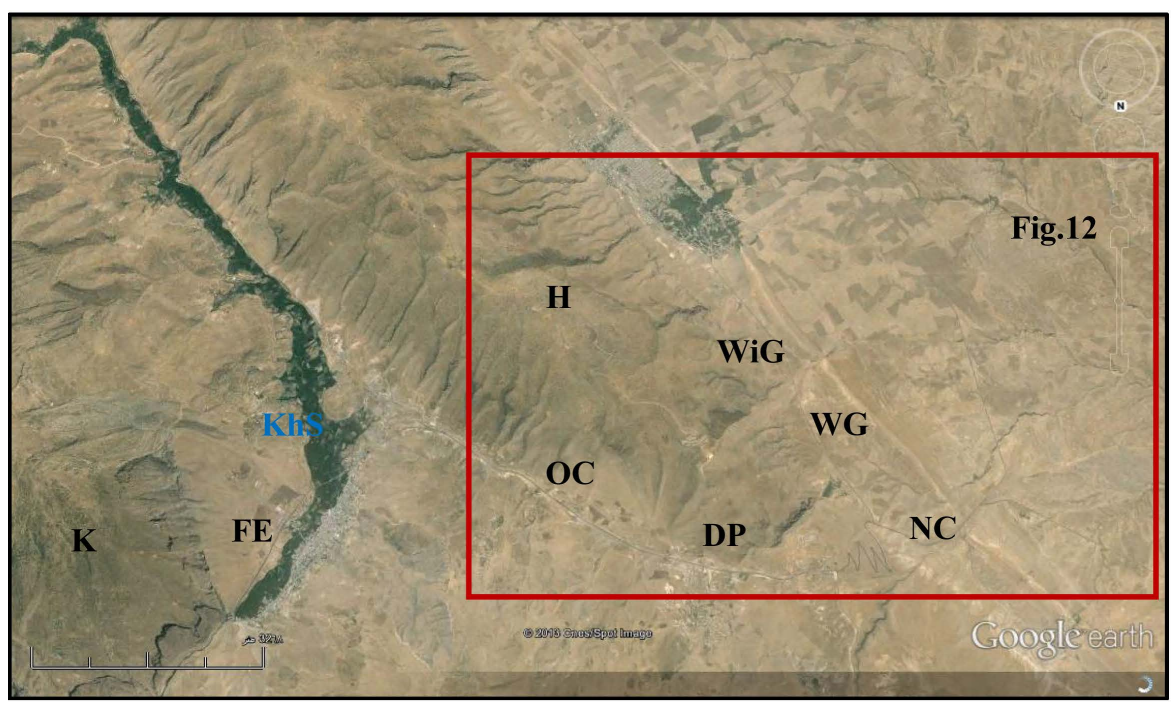

Figure 11. Google earth image (facing south). Note the old and recent courses of the Khlaifan stream. $\mathrm{H}=$ Hareer anticline; $\mathrm{K}=$ Korak anticline. Course of the stream; Kh S = Recent; $\mathrm{OC}=$ Old; FE = Fault escarpment. WiG = Wind gap; WG = Water gap; $\mathrm{DP}=$ Deflection point and NC = Old crossing of Khlaifan stream to Hareer anticline.

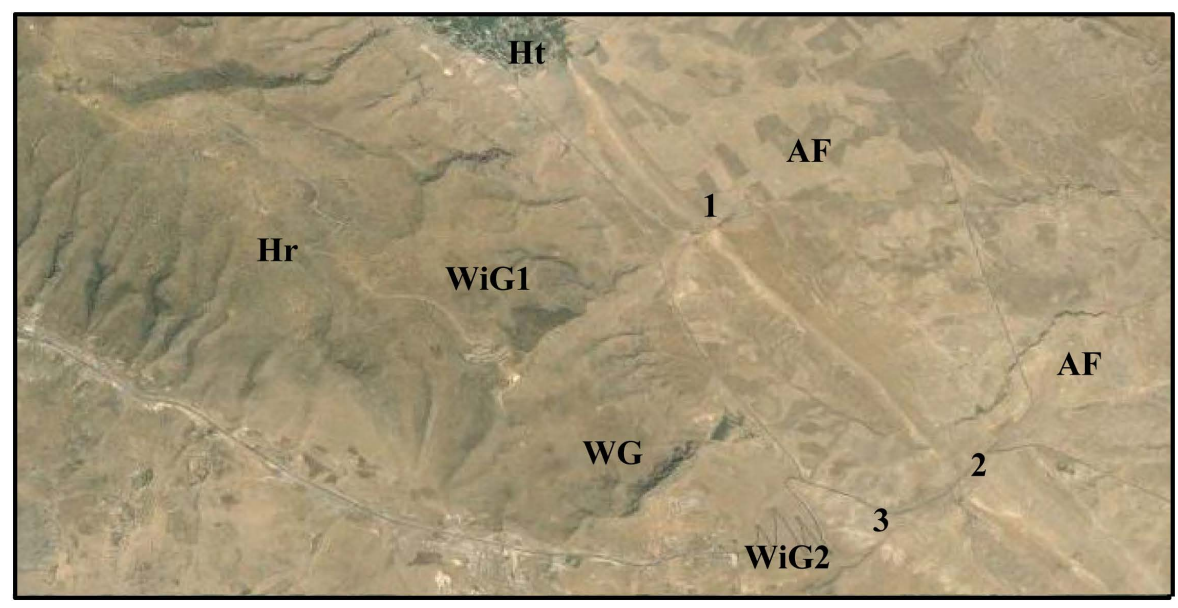

Figure 12. Google earth image (facing south). $\mathrm{Hr}=$ Hareer anticline; $\mathrm{Ht}=$ Hareer town; $\mathrm{AF}=$ Alluvial Fan; WiG = Wind Gap; WG = Water Gap.

down thrown block being towards Khlaifan stream, consequently deepening the right bank of the old course of the stream. 2) The lateral and vertical growth of Peris anticline (PA) and syncline (PS) have already met the northwestern plunge of Hareer anticline, in en-echelon pattern (H-P); consequently have blocked the passage of Khlaifan stream (Figure 13) and formed a trough between the Korak and Peris plunges, where the former exhibits high peak. 3) Most probably there was a stream running parallel to the plunge of Korak anticline, which was engulfed by the shifted Khlaifan stream, to be its new course, and 4) Korak anticline was growing vertically faster than laterally, as compared with other anticlines, such as Hareer (1423 m), Peris (1251 m), and Balikian (1527 m). The latter is represented by Garwa Pern peak in Balikian Mountain within Bradost Range and Zozik $(1861 \mathrm{~m})$. This is attributed to the absence of any wind and/or water gap along the anticline, besides its very high peak (2128 m), as compared to the others.

\subsection{Zil Gulley Stream}

The Zil Gulley stream is a main branch of the Rawandooz River; with which the stream merges at the northern entrance of the Gulley Ali Beg gorge (Figure 14). The Zil Gulley stream (ZS) was crossing Balikian anticline at 


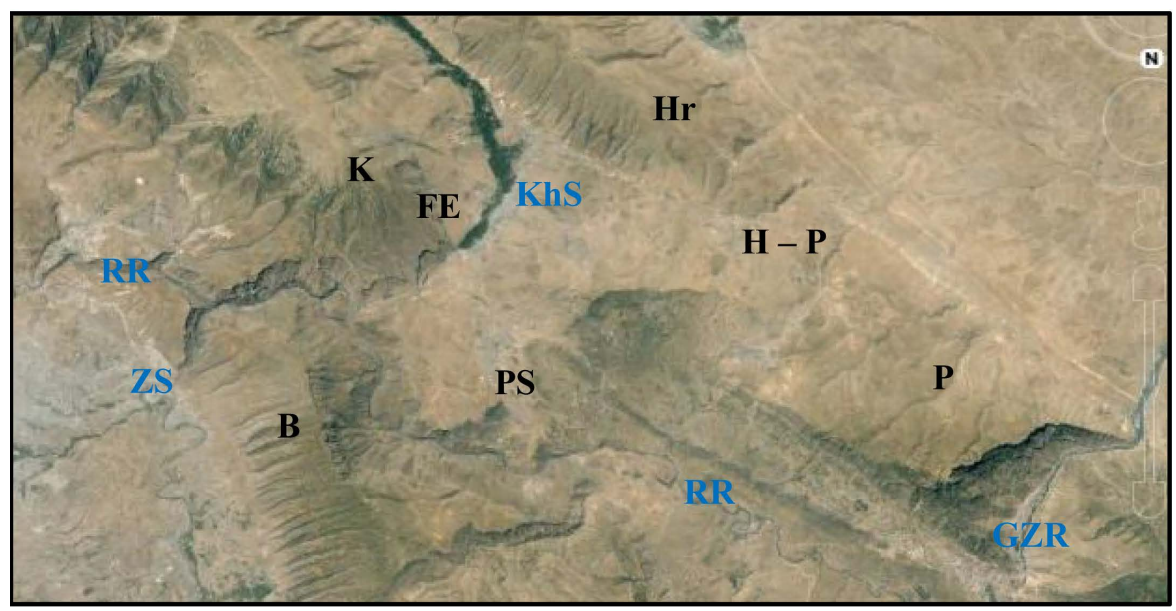

Figure 13. Google earth image (facing south). Anticlines: $\mathrm{Hr}=$ Hareer; $\mathrm{K}=$ Korak; $\mathrm{B}=$ Bradost; P = Peris; PS = Peris Syncline; FE = Fault Escarpment. Rivers: GZR = Greater Zab; RR = Rawandooz; Streams: KhS = Khlaifan; ZS = Zil Gulley.

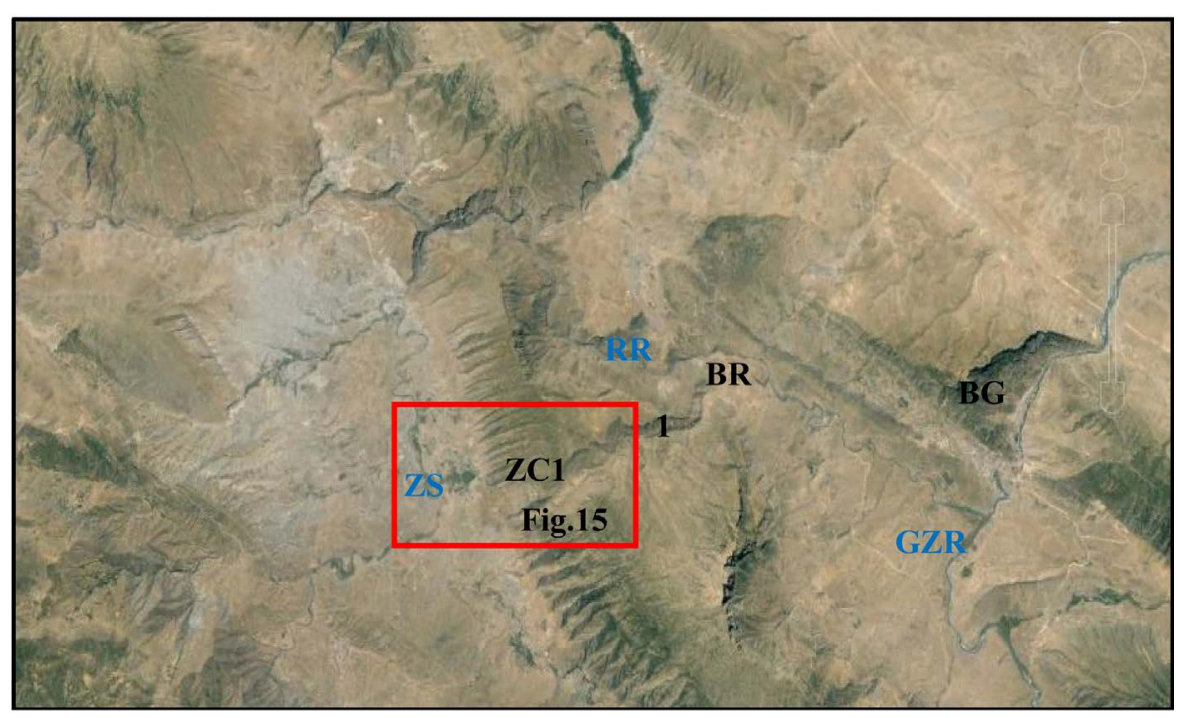

Figure 14. Google earth image facing south. Note the old course of Zil Gulley stream. ZS = Zil Gulley stream; ZC1 = Old course of Zil Gulley stream; BR = Merging point of old Zil Gulley stream in Rawandooz River; RR = Rawandooz River; GZR = Greater Zab River; BG = Bekhme Gorge.

its plunge area at ZC1 location (Figure 14). As Bradost anticline was laterally growing, as the stream was shifting southeastwards until it met the flowing Rawandooz River in the northern entrance of the gorge. The original crossing at ZC1 was abandoned forming a wind gap (ZC1 in Figure 14). It is still a wind gap, as seen in Figure 14. After crossing Bradost anticline it was merging with the Rawandooz River at BR location (Figure 14). This is evidenced from the size of the existing wind gap, as compared with the other valleys, which flow towards the southwest. If this was not the case, then the existing dry valley at the location of ZC1; wouldn't be in such size, with such incision ability, which has carved in Bradost anticline and even after crossing forming such deep cut valley (point 1, Figure 14).

Moreover, a landslide (LS) in the northern entrance of the old crossing of Zil Gulley stream to Bradost anticline had blocked the entrance (Figure 15), which contributed in abandoning the stream of its old course; leaving a wind gap (WG in Figure 15). The landslide was also recognized by Sissakian and Abdul Jab’bar (2010); they attributed the abandoning of the gorge to the mentioned landslide.

The parallel groves across Bradost anticline (Figure 14 and Figure 15), also indicate the continuous lateral 
growth of Bradost anticline, which had formed all those grooves along the carapace of the anticline. Some of the grooves have already crossed the whole anticline, forming nearly a set of wind gaps.

\subsection{Model of the Galley Ali Beg Gorge Evolution}

The aforementioned lateral and vertical growths of Hareer, Korak, Peris, Bradost, Handreen and Zozik anticlines, and the related shifts in the Rawandooz River, Khlaifan stream and Zil Gulley stream, forming the wind gaps and water gaps, due to abandoning of the drainage to their courses, which are shown in Figures 9-15, are demonstrated in Figure 16. The model is presented in three stages, which show the lateral growth of the anticlines and the shifting of the courses of Rawandooz River and Tanun, Khlaifan and Zil Gulley streams.

Figure 17 shows the Landsat images of the studied area; presenting the nowadays drainage net of the Rawandooz River and Tanun, Khlaifan and Ail Gulley stream. The model shown in Figure 16 and Figure 17 is the summary of the scenarios mentioned and discussed in this article.

\section{Conclusions}

Gulley Ali Beg gorge is developed due to lateral and vertical growth of the surrounding anticlines; Zozik, Bradost, Korak, Peris and Hareer.

The Rawandooz River, Tanun, Zil Gulley and Khlaifan streams have shifted their courses continuously, consequently Gulley Ali Beg gorge was developed and incised deeply in the thickly bedded and massive carbonates, exhibiting a very deep gorge; attaining $700 \mathrm{~m}$.

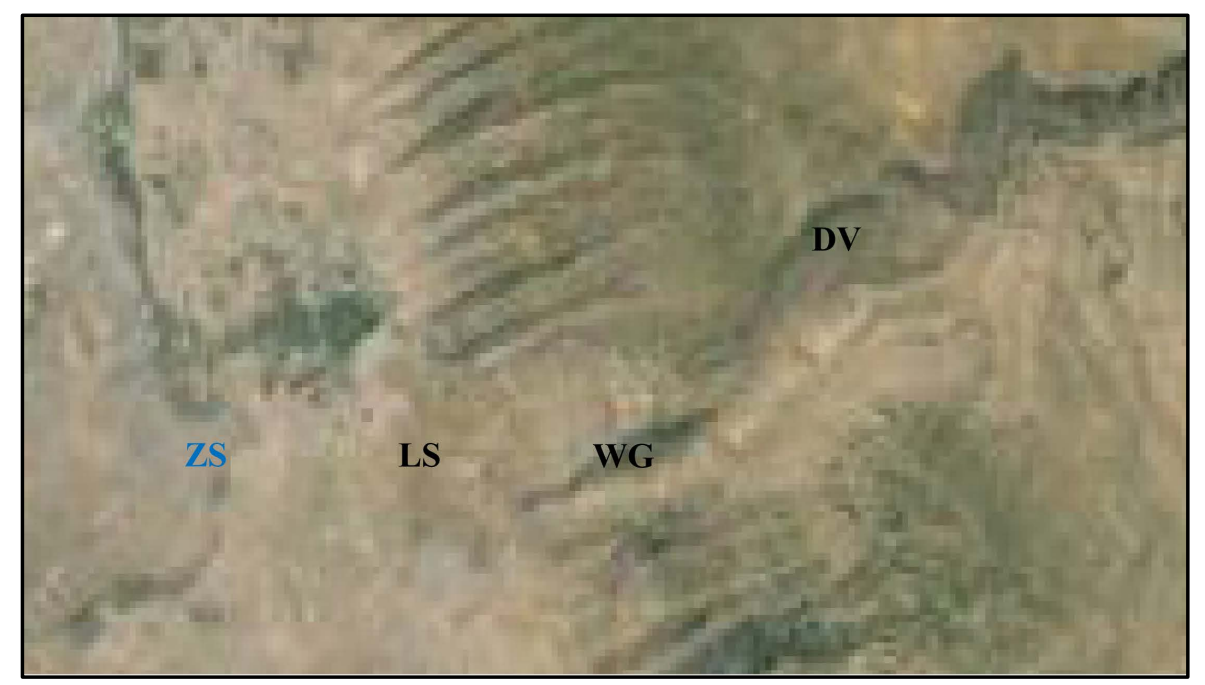

Figure 15. Google earth image, facing south. Note the details of the old course of Zil Gulley stream. ZS = Zil Gulley Stream; LS = Land Slide; WG = Wind Gap; DV = Deeply cut Valley.
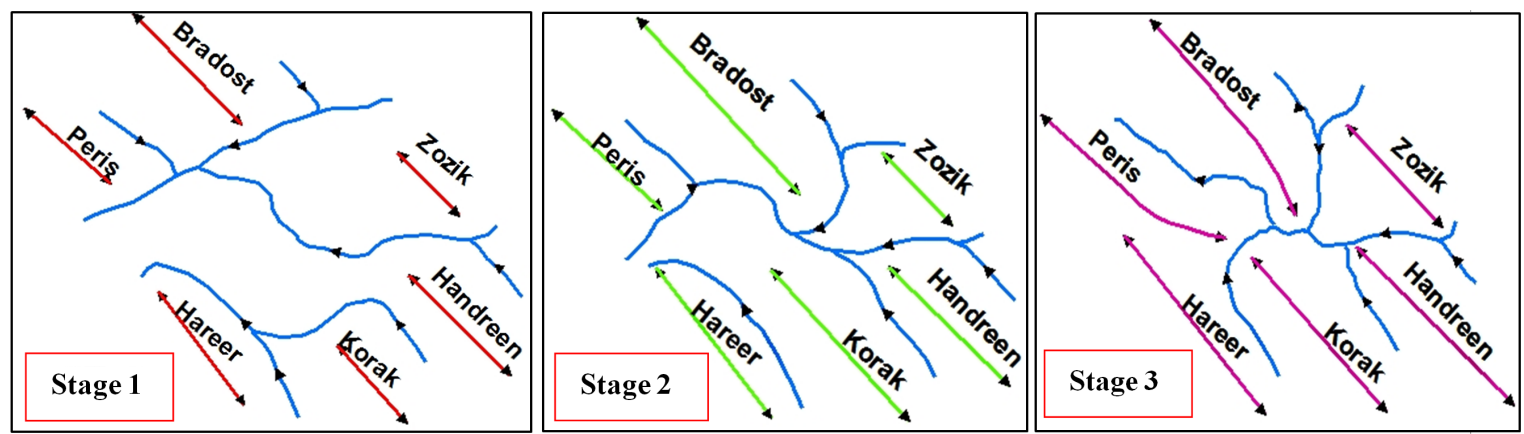

Figure 16. Diagrammatic model of the suggested scenario (three stages) for the growth of the anticlines and development of the Gulley Ali Beg gorge (facing north). 

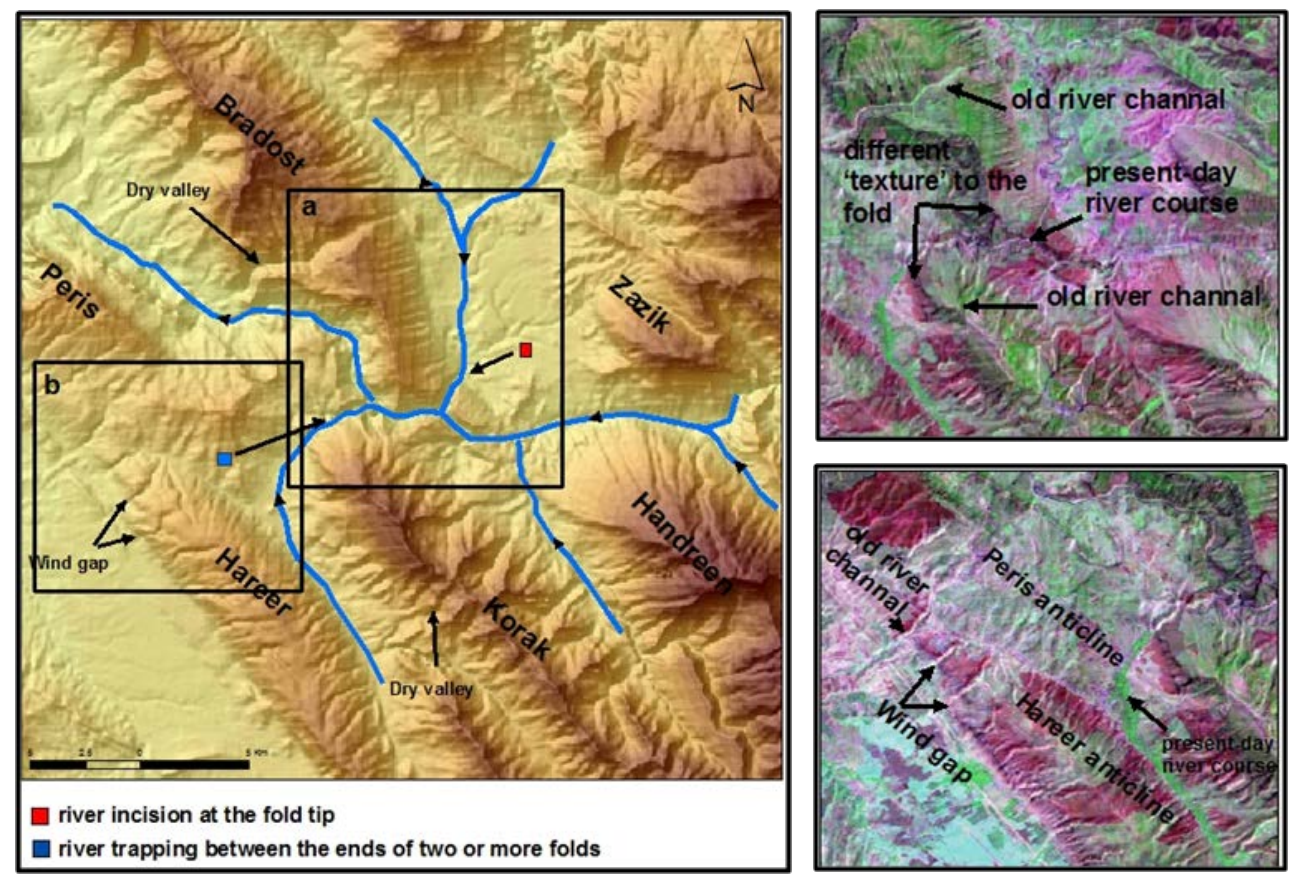

Figure 17. Landsat images of the studied area showing the nowadays courses of the drainage net (facing north).

In the area, some streams shifted their courses. This was due to many lanslides that contributed in shifting the river courses. In addition, many alluvial fans are present, which witness the mentioned scenario for shifting of the Khlaifan stream course. Many wind gaps and water gaps witness the lateral growth of the anticlines. Some of the wind gaps have returned as water gaps, due to the blockages of the courses.

\section{Acknowledgements}

The authors acknowledge the comments of Prof. Dr. Hikmat S. Al-Daghastani, which enhances the article. The efforts of Mr. Hayder $\mathrm{H}$. Taha for arranging the figures of the article and the presentation shown on them are acknowledged too.

\section{References}

[1] Al-Maamar, A.F., Khader, M.A. and Hattab, A.A. (2009) Geomorphological Study of Greater Zab River and Tributaries, Using Remote Sensing and GIS. Iraq Geological Survey Library Report No. 3249.

[2] Sissakian, V.K. and Abdul-Jab'bar, M.F. (2010) Morphometry and Genesis of the Main Transversal Gorges in North and Northeast Iraq. Iraqi Bulletin of Geology and Mining, 6, 95-120.

[3] Sissakian, V.K. (2010) Neotectonic Movements in Darbandi Bazian Area, Southwest of Sulaimaniyah City, NE Iraq. Iraqi Bulletin of Geology and Mining, 6, 57-69.

[4] Al-Maamar, A.F., Al-Saady, Y.I. and Al-Saati, R.M. (2011) Series of Geomorphological Maps of Iraq, Scale 1:250,000, Erbil and Mahabad Quadrangles, Sheets No. NJ-38-14 and NJ-38-15. Iraq Geological Survey Library Report No. 3358.

[5] Abdul Jab'bar, M.F. (2012) Effect of Neotectonics Activity on Selected Structures in North and Northeastern Parts of Iraq. Unpublished M.Sc. Thesis, University of Baghdad, Baghdad.

[6] Sissakian, V.K. and Abdul Jab'bar, M.F. (2015) Geomorphology and Morphometry of the Three Tributaries of Adhaim River, Central Part of Iraq. Accepted for Publication in Journal of Research in Environmental Science and Toxicology.

[7] Sissakian, V.K. (2013) Geomorphology and Morphometry of the Greater Zab River Basin, North of Iraq. Iraqi Bulletin of Geology and Mining, 9, 21-49.

[8] Sissakian, V.K. and Fouad, S.F. (2013) Geological Map of Rawandooz Quadrangle, Scale 1:100,000. 2nd Edition, Iraq Geological Survey Achieve, Baghdad.

[9] Sissakian, V.K. and Fouad, S.F. (2013) The Geology of Erbil and Mahabad Quadrangles, Scale 1:250,000, Sheets NJ- 
38-14 and NJ-38-15. 2nd Edition, Iraq Geological Survey Publications, Baghdad.

[10] Al-Kubaisi, M. and Abdul Jab’bar, M.F. (2013) Effect of Lateral Propagation of Selected Folds Onstreams, Sulaimaniyah Area, NE Iraq. Proceedings of the Scientific Conference of the Iraq Geological Survey, Baghdad, 14-15 December, 11-12.

[11] Sissakian, V.K., Kadhum, T. and Abdul Jab’bar, M.F. (2014) Geomorphology. The Geology of the High Folded Zone, Iraqi Bulletin of Geology and Mining, 7-56.

[12] Sissakian, V.K. and Fouad, S.F. (2012) Geological Map of Iraq, Scale 1:1000,000. 4th Edition, Iraq Geological Survey Publications, Baghdad.

[13] Jassim, S.Z. and Goff, J.C. (2006) Geology of Iraq. Dolin, Prague and Moravian Museum, Brno.

[14] Fouad, S.F. (2012) Tectonic Map of Iraq, Scale 1:1000,000. 3rd Edition, Iraq Geological Survey Publications, Baghdad.

[15] Sissakian, V.K. and Deikran, D.B. (1998) Neotectonic Map of Iraq, Scale 1:1000,000. Iraq Geological Survey Publications, Baghdad.

[16] Burbank, D.W. and Pinter, N. (1999) Landscape Evolution: The Interactions of Tectonics and Surface Processes. Basin Research, 11, 1-6. http://dx.doi.org/10.1046/j.1365-2117.1999.00089.x

[17] Burbank, D.W., Mclean, J.K., Bullen, M., Abdrakhmatov, K.Y. and Miller, M.M. (1999) Partitioning of Intermontane Basins by Thrust-Related Folding, Tien Shan, Kyrgyzstan. Basin Research, 11, 75-92. http://dx.doi.org/10.1046/j.1365-2117.1999.00086.x

[18] Ramsey, L.A., Walker, R.T. and Jackson, J. (2008) Fold Evolution and Drainage Development in the Zagros Mountains of Fars Province, SE Iran. Basin Research, 20, 23-48. http://dx.doi.org/10.1111/j.1365-2117.2007.00342.x

[19] Mukherjee, S. and Jaha, V.C. (2011) Morphotectonics and Resultant Features in Kaliani River Basin (Assam). Sociedade \& Natureza (Online), 23, 285-294. http://dx.doi.org/10.1590/S1982-45132011000200011 
Scientific Research Publishing (SCIRP) is one of the largest Open Access journal publishers. It is currently publishing more than 200 open access, online, peer-reviewed journals covering a wide range of academic disciplines. SCIRP serves the worldwide academic communities and contributes to the progress and application of science with its publication.

Other selected journals from SCIRP are listed as below. Submit your manuscript to us via either submit@scirp.org or Online Submission Portal.
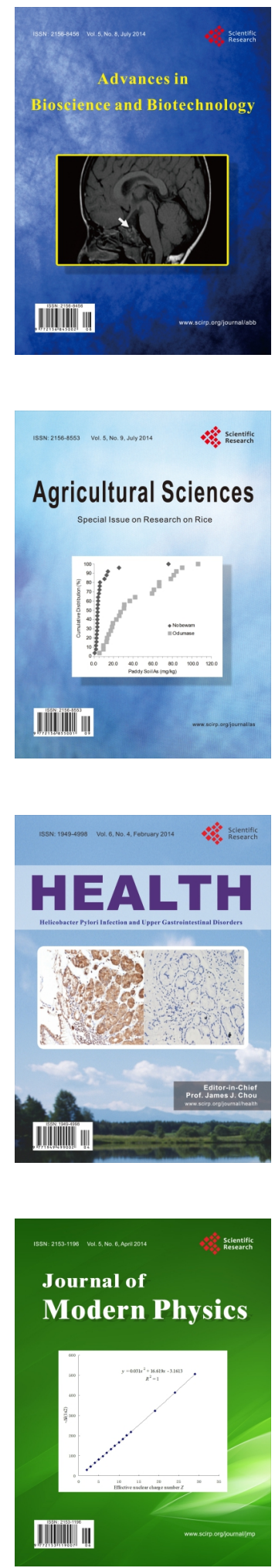
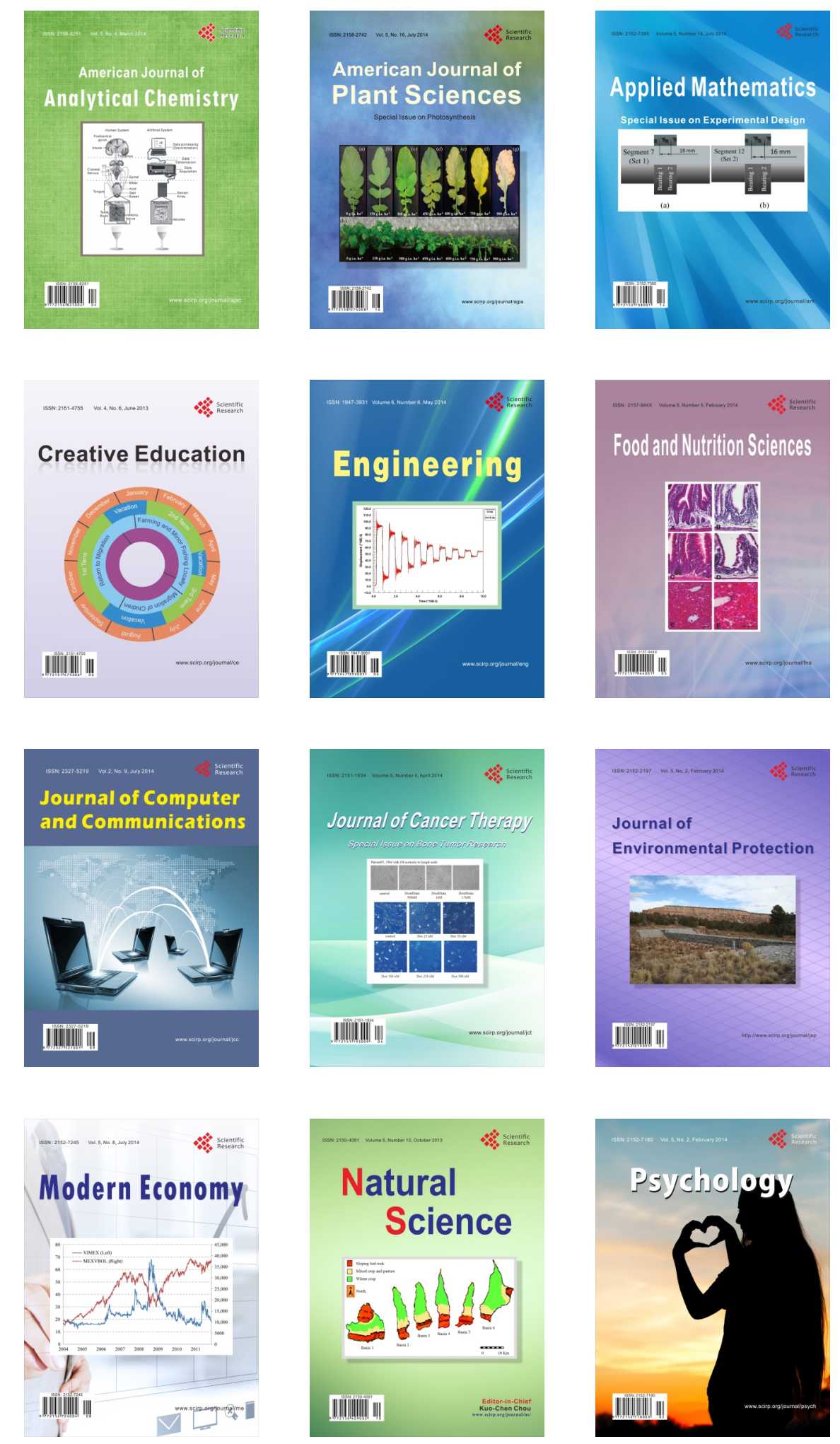